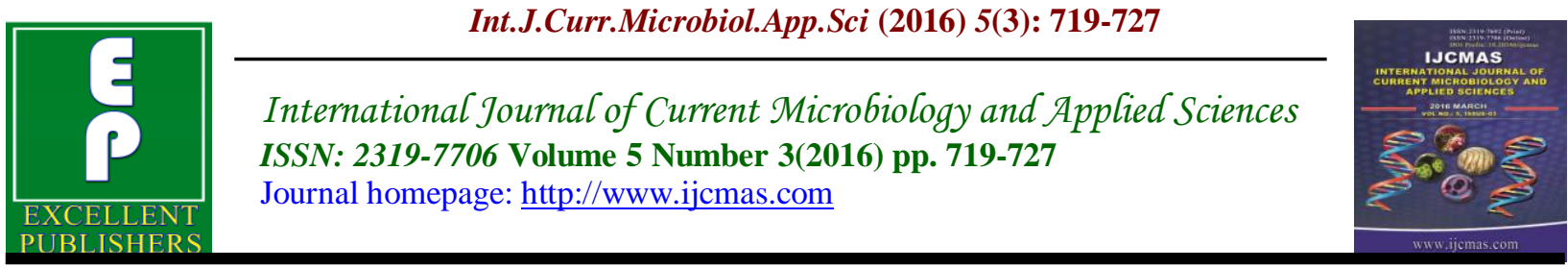

Review Article

http://dx.doi.org/10.20546/ijcmas.2016.503.084

\title{
A Review on Role of Nickel in the Biological System
}

\author{
Satish Kumar and A.V. Trivedi* \\ Department of Chemistry, Carrier point University, National Highway 12, \\ Alaniya, Kota 325003, Rajasthan, India \\ *Corresponding author
}

\section{Keywords}

Nickel in biology,

Enzyme, Toxicity,

Deficiency,

Global CO

balance,

Nitrogen fixation

\section{Article Info}

Accepted:

20 February 2016

Available Online:

10 March 2016
A B S T R A C T

This review was aimed to examine the role of nickel in biological system. Nickel plays awell defined role in biological system. Low nickel offers reduce growth this is particularly true of intra-uterine development. Nickel deficiency is also accompanied by histological and biochemical changes and reduced iron resorption and leads to anaemia. When nickel enters the body it is distributed to all organs, but mostly in the kidney, bone, and lungs. Toxicity of nickel arises from elemental nickel and inhaled nickel carbonyl, a carcinogenic gas that results from the reaction of nickel with heated carbon monoxide, from cigarette smoke, car exhaust, and some industrial wastes.Nickel based enzyme system is well known and plays an important role not only in life process but also in the global biological carbon, nitrogen, and oxygen cycles. Nickel is necessary for the biosynthesis of the hydrogenase, carbon monoxide dehydrogenase and found in a number of genera of bacteria. A nickel-tetrapyrrole coenzyme, Cofactor $\mathrm{F} 430$, is present in the methyl coenzyme $\mathrm{M}$ reductase, which powers methanogenic archaea. One of the carbon monoxide dehydrogenase enzymes CODH consists of an Fe-Ni-S cluster which helps to remove and oxidize 108 tons of $\mathrm{CO}$ from earth's lower atmosphere every year, helping to maintain low $\mathrm{CO}$ levels. The plant enzyme urease : an enzyme that assists in the hydrolysis of urea contain nickel. Urease is key to the global nitrogen cycle because it catalyzes hydrolysis of urea, which is a major globally used soil fertilizer.

\section{Introduction}

Nickel (Ni) is a naturally occurring metal existing in various mineral forms and it is present in all compartments of the environment and ubiquitous in the biosphere as nickel compounds and complexes. It is a silvery-white lustrous metal with a slight golden tinge. Nickel belongs to $3 \mathrm{~d}$ group transition metals and is hard and ductile. Nickel is one of the five ferromagnetic elements.
It is also a naturally magnetostrictive material, i.e. in the presence of a magnetic field, the material undergoes a small change in length (Hathaway and Clark, 1993). Nickel is used in a wide variety of metallurgical processes such as electroplating and alloy production as well as in nickel cadmium batteries. Besides it plays a well defined role in the biological system and plants (Sigel et al., 2008; Sydor 
and Zamble, 2013; Dixit et al., 2015) Nickel is necessary for the biosynthesis of the hydrogenase, carbon monoxide dehydrogenase (Can et al., 2014) and found in a number of genera of bacteria. A nickeltetrapyrrole coenzyme, Cofactor F430, is present in the methyl coenzyme $\mathrm{M}$ reductase, which powers methanogenic archaea (Stephen, 2014). One of the carbon monoxide dehydrogenase enzymes consists of an Fe-Ni-S cluster (Wang et al., 2014) .Urease from jack beans and several species of plants is also a nickel protein . The plant enzyme urease : an enzyme that assists in the hydrolysis of urea contains nickel. These plant enzyme systems can affect animals via the microbiological digestion of food in the rumen. Low nickel offers reduce growth, this is particularly true of intra-uterine development. Nickel deficiency is accompanied by histological and biochemical changes and reduced iron resorption and leads to anaemia. It's deficiency also results in lower activities of different dehydrogenases and transaminases and, affects carbohydrate metabolism. Nickel can have an impact on human health through infectious diseases arising from nickel dependent bacteria (Zambelli et al., 2013).

\section{Metabolism and Absorption of Nickel}

When nickel enters the body it is distributed to all organs, but mostly in the kidney, bone, and lungs (Samal and Mishra, 2011). If nickel enters the body with nickel contaminated air it is retained in the lungs. Nickel, which enters the blood stream is excreted in the urine, and if it is entered by the food it is excreted in the feces (Patriarca, 1997; Sunderman, 1989). Urinary excretion is the major route for the elimination of absorbed nickel. Fecal excretion primarily reflects the nickel that is unabsorbed from the diet and passes through the gut (Von,
1997). Nickel is poorly absorbed by the body. Less than $10 \%$ is absorbed in the gastrointestinal tract. In short and long-term studies of animal administered various soluble nickel salts orally, nickel was found primarily in the kidneys. The relative tissue concentrations were kidneys > lungs > liver $>$ heart > testes (Ambrose et al., 1976 ; Dieter et al., 1983). The normal ranges of nickel concentrations in body fluids or tissues (serum, blood, lung, kidney) are not significantly influenced by age, sex, or pregnancy. Oral administration of $\mathrm{Ni2+}$ found to accumulate higher in the spinal cord than in the cerebellum or frontal cortex (Brog, 1989). The chemical form and its deposition site as determined by size, shape, density, and electrical charge of the nickel particles will affect the extent of absorption in the lungs (ATSDR, 1988). Although nickel is poorly absorbed from the gastrointestinal tract but dietary exposure and exposure via drinking water provide most of the intake of nickel and nickel compounds (Goyer, 1991; Coogan, 1989).

\section{Biochemical and Physiological Functions of Nickel}

The biological function of nickel is still somewhat unclear. Nickel is found in the body in highest concentrations in the nucleic acids, particularly RNA, and is thought to be somehow involved in protein structure or function (Peter, 2015). It may activate certain enzymes related to the breakdown or utilization of glucose. Nickel may aid in prolactin production, and thus be involved in human breast milk production. Nickel aids in iron absorption, as well as adrenaline and glucose metabolism, hormones, lipid, cell membrane, improves bone strength and may also play a role in production of red blood cells (Wilfred, 2012). Nickel is present in RNA and DNA of our body where it functions in association with nucleic acids. 
It probably has a role in stabilizing RNA structure (Petzold, and Al-Hashimi, 2011).

\section{Absorbtion of Iron and Role of Nickel}

Nickel is believed to play a role in physiological processes as a co-factor in the absorption of iron from the intestine (Schnegg, 1976). The interaction between nickel and iron occurs only under certain conditions. Nickel increased the absorption of iron from the diet in iron deficient rats (female), but only when dietary iron was in the unavailable ferric form, whereas a mixture of ferrous and ferric sulphates $(60 \%$ ferric to $40 \%$ ferrous) as a supplement to the diet did not elicit any effect (Nielsen, 1980).

\section{Deficiency and Dietary Allowance of Nickel}

Since it is trace element, deficiency of it is rare. But it is found that due to low amount of nickel in the bodies of some individual certain liver and kidney diseases arise in them (Wilfred, 2012). It is definitely a problem in chicks and other small animals, where low nickel can lead to decreased growth, dermatitis, pigment changes, decreased reproduction capacities, and compromised liver function (Elson, 2016). In humans, increased sweating, such as from exercise, can cause nickel losses, and extra dietary nickel may be required to maintain its still mysterious function.

Generally nickel sulfate and nickel chloride are used as supplements. Recommended dietary allowance (RDA) for nickel for diffrent age group people have been reported by Acu-Cell Technology in 2016 (RDI, 2016): RDA for children up to 1-10 years both male and female is $100-300 \mu \mathrm{g} /$ day for 11-18 years male children and adolescent is 400-600 $\mu \mathrm{g} /$ day for female $300-500 \mu \mathrm{g} /$ day whereas, for $19+$ years male $500-700 \mu \mathrm{g} /$ day and for female 400-600 $\mu \mathrm{g} / \mathrm{day}$.

\section{Toxicity of Nickel}

Toxicity is the main concern here-not from elemental nickel or the nickel found in foods but from inhaled nickel carbonyl, a carcinogenic gas that results from the reaction of nickel with heated carbon monoxide, from cigarette smoke, car exhaust, and some industrial wastes. The lung and the skin are the principal target organs upon occupational exposure. inhalation exposure is a primary route for nickel-induced toxicity in the workplace. The most important adverse health effects due to occupational exposure to nickel and its compounds are skin allergies, lung fibrosis, and lung cancer (Zhao et al., 2009). The exact mechanisms of nickel-induced carcinogenesis are not clear.

Nickel carbonyl is toxic and can cause symptoms such as frontal headaches, nausea, vomiting, or vertigo with acute exposure. Nickel sulfide fume and dust are believed to be carcinogenic and various other nickel compounds may be as well. (Kasprzak, 2003) Inhaled nickel accumulates in the lungs and has been associated with increased rates of lung, nasal, and laryngeal cancers. The nickel in jewelry, dental materials, or prosthetic joints or heart valves may also be allergenic sources. Almost all cases of acute nickel toxicity result from exposure to nickel carbonyl. The initial effects involve irritation of the respiratory tract and nonspecific symptoms. Patients with severe poisoning develop intense pulmonary and gastrointestinal toxicity. Diffuse interstitial pneumonitis and cerebral edema are the main cause of death (Barceloux, 2000). Nickel and nickel compounds are wellrecognized carcinogens. Angina, skin rash, hypoglycemia, decreased estrogen, shortness of breath, asthma, nausea, lowered pulse, 
vomiting, diarrhea, headache, stomach irritation, increased protein in urine, increased red blood cells, heart failure are also reported as nickel toxicity syndrome (DRI, 2016).

\section{Nickel in Tobacco and Cigarettes}

Cigarette smoke is a complex aerosol consisting of a vapour phase and a particulate phase: some experimental evidence suggests that $\mathrm{Ni}$ may be approximately equally distributed between the two phases (Smith et al., 1997). A mean $\mathrm{Ni}$ concentration of $0.03 \mu \mathrm{g} / \mathrm{g}$ was reported in smoke condensate collected from different US brands of cigarettes, whereas, in most of the tobacco $\mathrm{Ni}$ was found to be present in the ash (Torjussen et al., 2003).

Ni can migrate from soil into tobacco plants and accumulate in the leaves. Its average concentrations in cigarette, pipe, and cigar tobacco from various geographical areas were found to vary from $<1$ up to $5.5 \mu \mathrm{g} / \mathrm{g}$; however, $\mathrm{Ni}$ content in tobacco is characterised by a remarkable variability (< 2-400 $\mu \mathrm{g} \mathrm{Ni/g)} \mathrm{reflecting} \mathrm{the} \mathrm{agronomic}$ practices and environmental conditions of growing tobacco plants (Chiba and Masironi, 1992, Stojanovi et al., 2004). According to Health Canada Ni levels in sidestream smoke can also be as high as $0.53 \mu \mathrm{g} /$ cigarette.

On the assumption that a cigarette can contain $\mathrm{Ni}$ at an average $1-3 \mu \mathrm{g}$ level, and that $10-20 \%$ of $\mathrm{Ni}$ is released from the cigarette into the mainstream smoke, it was estimated that $2-12 \mu \mathrm{g}$ of $\mathrm{Ni}$ could be inhaled for each pack of cigarettes smoked. Nickel alone from the cigarette is under the tolerable limit but, more importantly nickel carbonyl, a carcinogenic gas that results from the reaction of nickel with heated carbon monoxide is very-very harmful and a carcinogenic gas.

\section{Nickel Based Enzyme System}

To date eight nickel enzymes are known. These involve the use and/or production of gases ( $\mathrm{CO}, \mathrm{CO} 2$, methane, $\mathrm{H} 2$, ammonia, and O2) that play important roles in the global biological carbon, nitrogen, and oxygen cycles (Ragsdale, 2007). CODH interconverts $\mathrm{CO}$ and $\mathrm{CO} 2$; ACS utilizes $\mathrm{CO}$; the nickel ARD produces $\mathrm{CO}$; hydrogenase generates/utilizes hydrogen gas; MCR generates methane; urease produces ammonia; and SOD generates O2. These enzymes are discussed in the following paragraphs:

\section{Glyoxalase I (Gly I)}

The principal physiological function of glyoxalase $\mathrm{I}$ is the detoxification of methylglyoxal, which is a reactive 2oxoaldehyde that is cytotoxic at millimolar concentrations. Methylglyoxal is a byproduct of normal biological process and can chemically damage several components of the cell, such as proteins and nucleic acids. Glyoxalase I requires bound metal ions for catalysis. Divalent nickel is used (Ragsdale, 2007). In the presence of Gly I enzyme methylglycol is break up in to lactate and water following the reaction :

Methylglyoxal Glyoxalase-I( $(\mathrm{Ni}+) \quad$ lactate $+\mathrm{H} 2 \mathrm{O}$

\section{Acireductone Dioxygenase (ARD)}

ARD performs the penultimate step in the methionine salvage pathway following the reaction:

1,2-Dihydroxy-3-oxo-5-(methylthio)pent-1-ene $+\mathrm{O}_{2}$ ARD (Ni 2+) $\mathrm{HCOOH}+$ methylthiopropionate + $\mathrm{CO}$

ARD belongs to the cupin superfamily, and the structure reveals an octahedral high spin $\mathrm{Ni}(\mathrm{II})$ center, hexacoordinated by three histidines, one aspartic acid, and two waters 
(Goldsmith et al., 2006). Nickel acts as a Lewis acid, promoting attack by the peroxo intermediate on the nickel-ligated carbonyl group to generate a cyclic intermediate (D) that decomposes to $\mathrm{CO}$, formic acid, and a carboxylic acid.

\section{Nickel Superoxide Dismutase}

Nickel superoxide dismutase (Ni-SOD) is a metalloenzyme that, like the other superoxide dismutases, protects cells from oxidative damage by catalyzing the disproportionation of the cytotoxic superoxide radical (O2-) to hydrogen peroxide and molecular oxygen (Jason,2014). Superoxide is a reactive oxygen species that is produced in large amounts during photosynthesis and aerobic cellular respiration. The equation for the disproportionation of superoxide is shown below:

$$
\left.2 \mathrm{O}_{2}^{-}+2 \mathrm{H}^{+} \quad \text { Ni superoxide Dimutase ( } \mathrm{Ni2}+\right) \quad \mathrm{H}_{2} \mathrm{O} 2+\mathrm{O}_{2}
$$

$\mathrm{Ni}$-SOD emerged with the rise in $\mathrm{O} 2$ levels around 2 billion years ago (Zelko, 2002) as part of a cellular defense system against reactive oxygen species generated by various reactions associated with oxygen metabolism.

\section{Ni -Urease}

Ureases are the nickel-containing metalloenzymes of high molecular weight (Krajewska, 2012). They functionally, belong to the superfamily of amidohydrolases and phosphotriesterases (Holm, 1997) It is an enzyme that catalyzes the hydrolysis of urea into carbon dioxide and ammonia. The reaction occurs is given below:

$$
\left(\mathrm{NH}_{2}\right) 2 \mathrm{CO}+\mathrm{H}_{2} \mathrm{O} \quad \text { Ni-Urease } \quad \mathrm{CO}_{2}+2 \mathrm{NH}_{3}
$$

Urease activity tends to increase the $\mathrm{pH}$ of the system as it produces ammonia, a basic molecule. Ureases are found in numerous bacteria, fungi, algae, plants and some invertebrates, as well as in soils, as a soil enzyme. Urease is key to the global nitrogen cycle because it catalyzes hydrolysis of urea, which is a major globally used soil fertilizer (Ciurli, 2007). Urease is also a virulence factor for pathogens in the animal gut and urinary tract,promoting host colonization by neutralizing the low $\mathrm{pH}$ in the stomach (Ciurli, 2007).

\section{Ni-Fe-Hydrogenase}

$\mathrm{Ni}$-Fe-Hydrogenase is a type of hydrogenase, which is an oxidative enzyme that reversibly activates molecular hydrogen (Lubitz, 2007). The catalytic site on the enzyme provides hydrogen-metabolizing microorganisms a redox mechanism by which to store and utilize energy via the reaction :

$$
2 \mathrm{H}^{+}+2 \mathrm{e} \quad \text { Ni-fe-Hydrogenase } \quad \mathrm{H}_{2}(\Delta \mathrm{E} 0=414 \mathrm{mV})
$$

This is particularly essential for the anaerobic, sulfate-reducing bacteria of the genus Desulfovibrio. (Volbeda, 1996). The practical application of this enzyme is a renewable, more environmentally friendly energy source.

\section{Methyl-CoM Reductase (MCR )}

All biologically generated methane on earth derives from the catalytic activity of MCR in methanogenic microbes. An MCR isozyme also appears to catalyze anaerobic methane oxidation. MCR catalyzes the conversion of methyl-CoM (methyl-SCoM) (Janu 2007) and N7mercaptoheptanoylthreonine phosphate $(\mathrm{CoBSH})$ to methane following the reaction: CH3-COM+COBSH MCRNOL+7) CHA + COM-SS-COB 
Based on crystal structures of the inactive $\mathrm{Ni}$ (II) enzyme, MCR consist of a nickel hydrocorphin called coenzyme F430, in the subunit .F430 is the prosthetic group of the enzyme methyl coenzyme $\mathrm{M}$ reductase (Stephen, 2014 ). This enzyme catalyzes the release of methane in the final step of methanogenesis:

\section{CO Dehydrogenase (CODH)}

In enzymology, carbon monoxide dehydrogenase is an enzyme that catalyzes the chemical reaction

$$
\mathrm{CO}+\mathrm{H}_{2} \mathrm{O}+\mathrm{A} \quad \stackrel{\mathrm{Ni}-[3 \mathrm{Fe}-45] \mathrm{CODH}}{\mathrm{CO}_{2}}+\mathrm{AH}_{2}
$$

The 3 substrates of this enzyme are $\mathrm{CO}$, $\mathrm{H} 2 \mathrm{O}$, and $\mathrm{A}$, whereas its two products are $\mathrm{CO} 2$ and $\mathrm{AH} 2$. $\mathrm{CODH}$ catalyzes the reversible oxidation of $\mathrm{CO}$ to $\mathrm{CO} 2$. Remarkably, at low $\mathrm{Ph}$ values, $\mathrm{CO} 2$ reduction can exceed the rate of $\mathrm{CO}$ oxidation (Parkin 2007). Microbes remove and oxidize 108 tons of $\mathrm{CO}$ from earth's lower atmosphere every year, helping to maintain low ambient $\mathrm{CO}$ levels. $\mathrm{Ni}-[3 \mathrm{Fe}-$ 4S] CODH enzymes have been purified from anaerobic bacteria.(Jeoung et al. 2007; Dobbek, 2001) . CODH exists in both monofuctional and bifunctional forms. In the latter case, $\mathrm{CODH}$ forms a bifunctional cluster with acetyl-CoA synthase (ACS),With CO as the first substrate, ACS apparently initiates catalysis from the "closed" state as CO moves through the channel and binds to nickel.

\section{Acknowledgement}

Author thanks Career point university Kota and Dr. Gurudatt Kakkar for their needful suggestion and help.

\section{References}

Ambrose, A.M., Larson, P.S., Borzelleca,
J.R., Hennigar, G.R., 1976. Long term toxicologic assessment of nickel in rats and dogs. J. Food Sci. Technol. 13, 181-187.

ATSDR (Agency for Toxic Substances and Disease Registry,USA). 1988. Toxicological profile for nickel. Atlanta, GA, U.S.A.

Barceloux, D.G. 2000. Nickel. J. Toxicol. Clin. Toxicol. 38(7): 813-823.

Barondeau, D.P., Kassmann, C.J., Bruns, C. K., Tainer, J.A. and Getzoff, E.D. 2004.Biochemistry. 43, 8038-8047

Borg, K. and Tjalve, H. 1989. Uptake of $63 \mathrm{Ni2}+$ in central and peripheral nervous system of mice after oral administration: Effects of treatment with halogenated 8hydroxyquinolines. Toxicology. 54, 59-68.

Bryngelson, P.A., Maroney, M.J. 2007. In: Nickel and Its Surprising Impact in Nature (Eds.) Sigel A., Sigel H., Sigel, R. K. O. John Wiley \& Sons Ltd., West Sussex, United Kingdom. Pp. 417-444.

Can M., Armstrong, F.A. and Ragsdale, S.W. 2014. Structure, Function, and Mechanism of the Nickel Metalloenzymes, $\quad \mathrm{CO}$ Dehydrogenase, and Acetyl-CoA Synthase. Chemical Reviews. 114(8): 4149-4174.

Chiba, M. and Masironi, R. 1992. Toxic and trace elements in tobacco and tobacco smoke. Bulletin of the World Health Organization. 70, 269275.

Ciurli, S. 2007. Nickel and Its Surprising Impact in Nature. In:Metal Ions In Life (Eds.)

Sigel, A., Sigel, H. and Sigel, R. K. O.John Wiley \& Sons Ltd., West Sussex, United Kingdom. Pp. 241-278,

Coogan, T.P., Latta D.M., Snow E.T. and Costa M. 1989. Toxicity and 
carcinogenicity of nickel compounds, In: Critical reviews in toxicology, vol. 19 (Eds.)

McClellan R.O.editor. Boca Raton, F.L. C R C Press, U.S.A Pp. 341-84.

DRI (Dietary Reference Intake). 2016. Nickel. Acu-Cell Technology www.acu-cell.com/nico2.html

Dieter, M.P., Jameson, C.W., Tucker, A.N., Luster, M.I., French,J.E. and Hong, H.L.1988. Evaluation of tissue disposition, myelopoietic and immunologic responses in mice after long-term exposure to nickel sulphate in the drinking water. $J$. Toxicol Environ Health. 24, 356372.

Dixit R., Wasiullah, Malaviya D., Pandiyan K., Singh Udai B., Sahu A., Shukla R., Singh B.P., Rai J.P., Sharma Pawan K., Lade H. and Paul D., 2015. Bioremediation of Heavy Metals from Soil and Aquatic Environment: An Overview of Principles and Criteria of Fundamental Processes Sustainability. 7, 2189-2212 .

Dobbek, H., Svetlitchnyi, V., Gremer, L., Huber, R., Meyer, O. 2001.Crystal structure of a carbon monoxide dehydrogenase reveals a $[\mathrm{Ni}-4 \mathrm{Fe}$ 5S] cluster. Science. 293 (5533): 1281-1285.

Elson, H.M. 2016. Mineral : Nickel. www.healthy.net/scr/article.aspx?id= 2082 Environmental Protection Agency. 1986. Health assessment document for nickel and nickel compounds, Research Triangle Park, NC: Office of Health and Environmental Assessment, Environmental Criteria and Assessment Office, EPA-600/8- 83012F. NTIS PB86-232212.

Ernst, F.D., Vliet, A.H.M.V., Kist, M., Kusters, J.G. and Bereswill, S. 2007.
Nickel and Its Surprising Impact in Nature. In: Metal Ions In Life Science. (Eds.) Sigel, A., Sigel, H., and Sigel, R. K. O. John Wiley \& Sons Ltd., West Sussex, United Kingdom. Pp.545580.

Goldsmith, Ju. T., Chai, R.B., Maroney, S.C., Pochapsky, M.J. and Pochapsky, S.S. 2006. J. Mol. Biol. 363, 823-834.

Goyer, R. 1991. Toxic effects of metals. In: Casarett and Doull's toxicology 4th edn. (Eds.) Amdur, M.O., Doull, J.D., Klaassen, C.D. Pergamon Press, New York . Pp. 623-680.

Hathaway, K. and Clark A.E. 1993. Magnetostrictive materials. Material Research Society, Warrendale, PA, U.S.A. Pp. 34-41.

Hausinger, R.P., Karplus, P.A. 2001. Handbook of Metalloproteins (Eds.) Wieghardt K., Huber, R., Poulos, T.L. and Messerschmidt, A. John Wiley \& Sons Ltd., West Sussex, United Kingdom Pp. 867-879.

Holm, L. Sander, C. 1997. An evolutionary treasure: unification of a broad set of amidohydrolases related to urease. Proteins. 28 (1): 72-82.

Jason, S. 2014. Insight into the Structure and Mechanism of Nickel-Containing Superoxide Dismutase Derived from Peptide-Based Mimics. Accounts of Chemical Research. 47, 2332-2341.

Jaun, B., Thauer, R.K. 2007. In: Nickel and Its Surprising Impact in Nature. (Eds.) Sigel A., Sigel H., Sigel R. K. O. John Wiley \& Sons Ltd., West Sussex, United Kingdom Pp. 323356.

Goldsmith, R.B., Chai, S.C., Maroney, M.J., Pochapsky, S.S., and Pochapsky, T.C. 2006 J.Mol. Biol. 363, 823834.

Kasprzak, S.F.W., and Salnikow, K. 2003. Nickel carcinogenesis. Mutation 
research. 533(1-2): 67-97.

Krajewska, B.van Eldik R, Brindell, M. 2012. Temperature- and pressuredependent stopped-flow kinetic studies of jack bean urease. Implications for the catalytic mechanism. JBIC Journal of Biological Inorganic Chemistry. 17(7): 1123-1134.

Lindahl, P.A., Graham, D.E. 2007 In: Nickel and Its Surprising Impact in Nature (Eds.)

Sigel A., Sigel H., Sigel R.K.O. John Wiley \& Sons Ltd., West Sussex, United Kingdom. Pp. 357-416.

Nielsen, F.H. 1980. Effect of form of iron on the interaction on nickel and iron in rats: Growth and blood parameters. J. Nutr.110, 965-973.

Parkin, A., Seravalli, J., Vincent, K.A., Ragsdale, S.W., and Armstrong, F.A. 2007. Carboxydothermus hydrogenoformans $\mathrm{CO}$ dehydrogenase-I on an electrode. J. Am. Chem. Soc. 129(34): 10328-10329.

Patriarca, M., Lyon, T.D. and Fell, G.S. 1997. Nickel metabolism in humans investigated with an oral stable isotope. Am. J. Clinical Nutrition. 66(3): 616-621.

Peter, T. Chivers. 2015. Nickel recognition by bacterial importer proteins. Metallomics. 7, 590-595.

Petzold, K. and Al-Hashimi, H.M. 2011, RNA structure: Adding a second dimension. Nature Chemistry. 3, 913-915.

Pochapsky, T.C., Ju T., Dang, M., Beaulieu, R., Pagani,G.M. and Ouyang B. 2007. In:

Nickel and Its Surprising Impact in Nature (Eds.) Sigel A., Sigel H., Sigel R.K.O. Pp. John

Wiley \& Sons Ltd., West Sussex, United Kingdom. Pp. 473-500.

Ragsdale, S.W. 2003. In: The Porphyrin
Handbook. (Eds.) Kadish,K.M., Smith, K.M. and

Guilard, R. Academic Press, New York.Pp. 250-228.

Ragsdale, S.W. 2007. J. Inorg. Biochem. 101, 1657-1666.

Ragsdale, S.W., Pierce, E. 2008. Biochim. Biophys. Acta. 1784, 1873- 1898.

Samal, L. and Mishra, C. 2011. Significance of Nickel in Livestock Health and Production. IJAVMS. 5(3): 349-361.

Schnegg, A. and Kirchgessner, M.1996. Absorption and metabolic efficiency of iron in nickel deficiency. International Journal of Vita. and Nutr. Research. 46(1): 96-99.

Sigel, A., Sigel, H. and Sigel, R.K.O. 2008. Nickel and Its Surprising Impact in Nature. In: Metal Ions in Life Sciences 2 (Eds) Sigel, A., Sigel, H. John Wiley \& Sons, Ltd. Chichester, U.S.A.

Smith, C.J., Livingston, S.D. and Doolittle, D.J. 1997. An international literature survey of "IARC Group I carcinogens" reported in mainstream cigarette smoke. Food and Chemical Toxicology. 35, 1107-1130.

Stephen, W.R. 2014. "Chapter 6. Biochemistry of Methyl-Coenzyme M Reductase: The

Nickel Metalloenzyme that Catalyzes the Final Step in Synthesis and the First Step in Anaerobic Oxidation of the Greenhouse Gas Methane". In: The Metal-Driven

Biogeochemistry of Gaseous Compounds in the Environment. Metal Ions in Life Sciences 14.(Eds.) Peter, M.H. Kroneck and Martha, E. Sosa Torres. Springer.U.S.A. Pp. 125-145.

Stojanovi, D., Niki, D. and La arevi, K. 2004. The level of nickel in smoker's blood and urine. Central European Journal of Public Health. 12, 187189. 
Sukdeo, N., Daub, E. and Honek, J.F. 2007. In: Nickel and Its Surprising Impact in Nature (Eds.) Sigel, A., Sigel H. and Sigel R. K. O. John Wiley \& Sons Ltd., West Sussex, United Kingdom. Pp. 445-472.

Sunderman Jr. F.W.,Hopfer, S.M., Sweeney, K.R., Marcs, A.H., Most, B.M., and Creason, j. 1989. Nickel absorption and kinetics in human volunteers. Proceedings of the Society for Experimental Biology and Medicine. 191(1): 5-11.

Sydor, Andrew M. and Zamble, Deborah B. 2013. "Chapter 11 Nickel Metallomics: General Themes Guiding Nickel Homeostasis".In: Metallomics and the Cell. Metal Ions in Life Sciences 12. (Eds.) Banci, Lucia . Springer. U.S.A.

Torjussen, W., Zachariasen, H. and Andersen, I. 2003. Cigarette smoking and nickel exposure. Journal of Environmental Monitoring. 5, 198-201.

Vignais, P.M. and Billoud, B. 2007. Chem. Rev. 107, 4206-4272.

Volbeda, A., Garcin, E., Piras, C. de., Lacey, A.L., Fernandez, V. M., Hatchikian, E.C., Frey, M. and FontecillaCamps, J.C. 1996. "Structure of the [NiFe] Hydrogenase Active Site: Evidence for Biologically Uncommon Fe Ligands". J. Am. Chem. Soc. 118 (17): 7045-7055.
Von, B.R. Nickel and some nickel compounds. 1997. J. Appl. Toxicol. 17(6):425-431.

Wang, V.C.-C., Ragsdale, S.W. and Armstrong, F.A. 2014. Investigations of the Efficient Electrocatalytic Interconversions of Carbon Dioxide and Carbon Monoxide by Nickel-

Containing Carbon Monoxide Dehydrogenases In: The MetalDriven Biogeochemistry of Gaseous Compounds in the Environment ; Metal Ions in Life Sciences 14. (Eds.)

Peter M.H., Kroneck, Martha E. and Sosa Torres. Springer, U.S.A. Pp. 71-97.

Wilfred, R.C. 2012. Nickel : The trace mineral that aids in iron absorption, as well as adrenaline and glucose metabolism. www.blissreturned. wordpress.com/2012/02/29/nickel

Zambelli, B. and Ciurli, S. 2013. Nickel: and Human Health". In: Metal Ions in Life Sciences 13 "Interrelations between Essential Metal Ions and Human Diseases" (Eds.)

Astrid Sigel, A., Sigel, H. and Sigel, R.K.O. Springer, U.S.A. Pp. 321-357.

Zelko, I.N., Mariani, T.J., and Folz, R.J. 2002. Free Radic. Biol. Med. 33, 337-349

Zhao, J. Shi, X. and Castranova, V. Ding M. 2009, Occupational toxicology of nickel and nickel compounds, 28(3):177-208.

\section{How to cite this article:}

Satish Kumar and A.V. Trivedi. 2016. A Review on Role of Nickel in the Biological System Int.J.Curr.Microbiol.App.Sci. 5(3): 719-727. doi: http://dx.doi.org/10.20546/ijcmas.2016.503.084 